\title{
Student Participation in Classroom Discussions
}

\author{
Mina Mahdikhani $^{1}$, Soheilahamzehloo ${ }^{2}$, Maryamshayestefard ${ }^{3}$, Nasrin Mahdikhani ${ }^{4}$ \\ ${ }^{1}$ Instructor at Farhangian University, Isfahan, Iran \\ ${ }^{2}$ B.A in English Language Teaching, Farhangian University, Isfahan, Iran \\ ${ }^{3}$ B.A in English Language Teaching, Farhangian University, Isfahan, Iran \\ ${ }^{4}$ M.A in Persian literature, Zanjan University, Zanjan, Iran
}

\begin{abstract}
This paper aims to reveal the importance of student participation in classroom discussions and review some of the most salient definition on classroom participation, and also bring some reasons students do or do not participate in class logistics. At the end of the paper we also have some benefits of getting students to participate in Classroom discussions. Here we give a comprehensive overview of the benefits of participation, logistical issues in participation, student confidence and personality traits in participation, the instructor's influence on and suggestions for increasing participation, the role of sex in participation, and participation in web-based courses. Finallywe concluded that the ideal class discussion" as one in which all students were participating, learning, and listening to others' ideas, comments, and questions, is important for the success of the class.
\end{abstract}

Keywords: Student Participation, College Classroom, Student Confidence, Sex.

\section{Introduction}

Any educational system tries to provide students with the best possible conditions and towards the best educational achievements through effective strategies and policies. Elites of the world of education consider the teacher and his abilities as the most important factor in any educational process. One such ability is providing a good environment for student participation. Class participation is important for the success of the class, before considering the importance of classroom participation, it is first necessary to define the term. Wade (1994) considered the "ideal class discussion" as one in which all students were participating, learning, and listening to others' ideas, comments, and questions. With this definition, it seems that it would still be possible to be passively engaged in the classroom experience. Participation also has been defined as "the number of unsolicited responses volunteered" (Burchfield \&Sappington, 1999, p. 290). The fact that researchers have similar but nearly different definitions of participation and its measurement should be kept in mind.In this article

\section{Participation; Definition and Thought}

Though teachers all tend to find out more about "class participation," and many use it in assessing students'development, what may or may not be counted as "participation" is different through individual instructors and researchers. Participation can be seen as an active involvement process which can be divided into five classifications: preparation, contribution to discussion, group works, communication skills, and attendance [1]. It is indicated that faculty perceive six levels of participation from students, moving from simply attending class through giving oral presentations [2][3] participation has been seen in different forms, including students' questions and comments [4], and it can take a short while or an extended period of time [5] [6] considered the "ideal class discussion", as one in which almost all students participate and are involved, learning, and listening to others' comments and concepts (p. 237). It seems that researchers and instructors favor these mainly quantitative and overt means of defining participation. Although the quality of student participation is crucial, it is also much more subjective can cause some kinds of struggles and challenges. [7] Small group discussions is a good way to force students to become actively and decisively involved in the classroom discussion. He mentioned that in these small groups, students "feel like they are becoming members in the discursive community." As Mortimer Ladler once noted, "All genuine learning is active, not passive. It involves the use of the mind, not just the memory. It is the process of discovery in which the student plays the main role, not the teacher." The challenge for teacher becomes, how do you illicit the type of active participation and true replacement of ideas that we anticipate in a college classroom?

\subsection{Class participation; Benefits}

There is strong evidence for the importance of participating in class [8].Participation is a good technique to involve "students actively into the educational process" and to assist in "increasing our teaching and bringing positive energy to the classroom" [9]. Students are more interested [10], learn better [11], become better critical thinkers [12], and have self-confidence.

Gainsin character [13] when they are prepared for class and participate in discussions. The more they participate, the more theyacquire, themore they do, and the more they engage in higher levels of thinking, including interpretation, analysis, and synthesis [14]. Students who participate also show development in their communication skills [15] group interactions [16] and functioning in a democratic society [17].[18] Considering that both students and teachers can see the advantages of student participation, and [19] found that students thought participation was "essential" to their own learning. Students have been found to earn higher grades as their participation enhances [20]. 


\section{International Journal of Science and Research (IJSR) \\ ISSN (Online): 2319-7064}

Index Copernicus Value (2013): 6.14 | Impact Factor (2015): 6.391

Though students see participation as important, and onethird would like to participate more [21] research suggests that it is not happening, as it is only a handful of students in any given classroom who participate more [22] a phenomenon appeared "consolidation of responsibility" ( $\mathrm{p}$. 429). This outcome has been reconfirmed decades later in several studies [23].[24] found that about 90\% of interactions were made by a handful of students and only around one-third were regular participators, while half 188 K. A. Rocca of the students observed did not participate at all. [25] found that an average of only around one minute of a 40-minute class period was spent in student participation.[26] and [27] found that students asked only 3.3 and 3.6 questions per hour of class time, respectively, and around $73 \%$ of these were in reference to procedures, content, or clarification). Although instructors, researchers, and students all appear to perceive the importance of and seemingly want to raise participation, many students do not participate for multiple causes.

\section{Why Door Do Not Students Participate in Class Logestics}

There are various reasons, both speculative and empirically maintained, that students are not able to participate in class. One reason is class size, with students being more willing to participate [28] less worried about participating [29] and less likely to be able to "hide" in smaller classes than larger classes; large class size tends to ease communication. [30] found class size to be more predictive of participation than gender [31] proved that while the number of students who participate in any given classroom is often the same, courses which have more than 40 students have fewer overall communications per class period. [32] found this to be true for courses with over 35 students, and [33] found small differences based on class size in their assessment of courses with 16_50 students.

Auster and [34] found that the courses where students reported the most participation were likely to be smaller (i.e., 10 or fewer students) than those where students reported the least participation (i.e., 40 or more students). Often, morelecturing oftenoccurs in larger classes, which, in turn, means less participatory opportunity for students. It also is possible that just the perception of being in a large class can deter participation. For example, a course of 30 students at one university might be small, but could be perceived as large by students at another university. Largesize classes, however defined, are not something we can remove on our college campuses, and thus, educators must find means to admire participation, not considering the classsize. To overcome the issue of large class size, [35] suggested that students meet for smaller weekly discussion sessions with former students who had performed well in the course, and they reported that this worked well in the classroom during a trial period. Dividing the large class into smaller groups also can be helpful to facilitate discussion and to increase group activities [36] also offered ways to encourage communication in large classes, including making the lecture hall feel small and thus personal*even if it is not*by moving around and by talking with the students before class, and [37] noted the importance of moving into closer proximity of the Student Participation 189 students.
These suggestions are similar to instructors' nonverbal propinquitytreatments, which also have been found to increase participation.

Seating arrangement is another logistical variable which affects student participation. Even as far back as 1958, seating arrangement was considered to be acrucial factor. Though each seating arrangement can serve a purpose, [38] noted that certain arrangements and specific seats within each arrangement were more conducive to student participation. Traditional forms of seating allows for less participation than a U-shaped/circular/semicircular arrangement .Bowers (1986) found no relationship among student seating preference and classroom apprehension, but [39] found that those high in apprehension feel more anxious and stressed out in circular seating. [40] Suggested that whether or notstudents participate depends on how much their participation counts toward theirfinal grades. The " "pearls of wisdom" approach where students record theirparticipation each day to count toward their end of semester scores was found tobe effective in increasing participation in the assessed course and reported to increaseparticipation in other fields. [41] Suggestedthat students should earn extra glory rather than counting participation as part ofa student's grade, and [42] found thatrewarding students with extra credit did increase participation.Allowing students to take a part in participation grading process is helpful inincreasing their quantity and quality of participation, attendance, and preparingfor class, and students are appreciative of having a say intheir participation grades .[43] found that when studentshelped to define class rules on participation, they were more likely to participate.[44] Found student selfmonitoring (i.e., observing and recording one'sown behavior) of their own in-class participation to increase participation overall, asrecorded by an outside observer. Moreover [45] foundthat giving students a mid-semester assessment of their participation encouragedincreased participation throughout the semester.

The type of course can have an impact on whether students participate. Notsurprisingly, students are more likely to participate and feelease in communication courses than those in the other socialsciences or the natural sciences. Students are more interested in asking questions in thenatural sciences than in the arts or social classes, but more likely to talk for longerperiods of time in the arts and social sciences than the natural sciences. Whether a course was a requirement or an electivedid not impact studentreported comfort level, but did impactpreference for seating type with the U-shaped arrangement preferred by those inelective courses, and the row/column arrangement preferred by those in requiredcourses Students in higher level courses were morelikely to participate than those in lower classification courses .A professor's use of media in the classroom can influence student participation.Playing on the Millennial generation's need for interaction, [46] created a learning stuff called the "Random Selector Model" to increasestudent participation through an interactive software program where the instructor isable to "randomly select" students and groups of students to participate in class. Theauthors note positive student outcome and encourage 


\section{International Journal of Science and Research (IJSR) \\ ISSN (Online): 2319-7064}

Index Copernicus Value (2013): 6.14 | Impact Factor (2015): 6.391

instructors to use this model asa supplement to their own courses.

\section{Confidence and Classroom Apprehension}

Another reason that students may not participate in class is because they are afraid of feeling inadequate in front of others, regardless of the logistics of theclassroom setting. [47], [48], and [49] all noted that students may feel intimidated or inadequate in front of theirclassmates and professors, and as the result choose not to participate. Students even reportedconfidence as the most motivating factor for their participation in several studies.

This concern about being nervous and lacking confidence follows closely withMcCroskey's research on communication apprehension, which can be trait- or situation-specific. Individuals who may not be particularlyhigh in communication apprehension as a trait are still frequently worried aboutcommunicating in certain conditions (e.g., public speaking, meetings). Confidence gained by advanced preparation helps to counteract classroomapprehension, as documented by the fact that students who were supposed to talk aboutthe topic with another student or to complete it as a homework assignment beforediscussing it with the entire class were more likely to participate[50] also made severalrecommendation to increase participation by all class members through advancedpreparation. He asked students to complete readings as homework and bring toclass the top five words to explain the readings; in class, words are written on theboard and students explain why they were selected. He also suggested brainstormingwhat the lesson would cover while in class and using role-playing debates to increaseparticipation through advanced preparation. [52] suggested having studentsprepare discussions in advance for weekly debates, and [53] suggestedallowing students to go over their answers with a partner or in a group beforestating the answers out loud to the class. [54]Also promoted advanced preparation to increaseparticipation.

Confidence gained by classroom experience may impact willingness to participate. This is evidenced by the fact that students who are young, inexperienced, andimmature are less likely to participate in classespecially if they are surrounded by others who are moreexperienced .Nontraditional students (generally defined as those 25years of age or older in undergraduate programs) are more likely to participateas are older traditional students (e.g., juniors, seniors). Nontraditional students are more likely to be concerned with what theinstructor thinks; whereas, traditional students are more likely to be concerned with 192 K. A. Roccawhat their partners think, and either could prevent students from participating. Prior experience with interpersonal and group communicationincreases students' participation.Closely related with the notion of feeling comfortable and confident in speaking inclass, [55] found that students who did notspeak English as their first language were less likely to participate. For internationalgraduate students, the biggest reason not to participate was if they did not know thematerial well, or felt a '"negative classroom climate,',.In courses where East Asian students are learning to speak English, they are said toappreciate the opportunity to participate more and practice the language, but theystill tend to feel hesitant and uncomfortable in doing so.Similarly, students who see themselves as minorities are less likely to participate inclass .In several ways, student confidence plays a role in one's level ofparticipation in any given course.

\section{Personality Traits}

To this point, Communication Apprehension (CA) has been discussed in terms ofsituational, or classroom-specific apprehension, but there also has been research onCA as a trait and its impact in the classroom. For example, [56]found that students high in CA participated more when the task at hand was morestructured, and she recommended offering choices in assignments that involveparticipation so that even those with high CA can participate more comfortably.[57], however, did find low self-esteem in general to be predictive of lowlevels of class participation.

Students' assertiveness and/or responsiveness also appear to determine whether ornot they will participate in class. Those who are high in both traits are more likely tocommunicate for functional reasons, and those who are more assertive are morelikely to communicate for excuse-making reasons.It also appeared from this study that students may participate for reasons dependent upon the instructor's personality combination of both assertiveness and responsiveness. Specifically, when both student and instructors were high in both assertiveness and responsiveness, students communicated for relational and sycophantic reasons,Student Participation 193 and when instructors were responsive and students assertive, students communicated for participatory reasons.Chan and [58] found that students high in the personality trait ofWillingness to Communicate (WTC) were more likely to participate in class than those low in WTC across the course of the semester Students with an external locusof control and those high in neuroticism andinsecurity were less likely to participate. Similarly, students withsocial anxiety, those higher in private selfconsciousness, and those with amixture of the two characteristics were less likely to participate to in-class group discussions.Impact of the Instructor and Classroom Climate On top of classroom logistics, student confidence, and student personality traits, there is still evidence that the instructor contributes to students' levels ofparticipation, and students think that their professors influence their participationbased on the ways in which the professors communicate with them .[59] found that "the actions of the teacher are indeed most vital in helping classroom interaction"' (p. 426) and [60] believe thata main reason students do not participate may be because of the teacher.

Specifically, students are less likely to participate if their instructors do not payattention to them, make fun of them, put them down, or are very serious of them.Similarly, [61] found that offensive behaviors involved by instructors, including using sarcasm and putdowns, being verballyabusive toward students, sexually harassing students, and having a negativepersonality had a negative influence in the classroom and on student learning, and[62] found that teachers who were considered "boring, bored, pushy,moody, close-minded, too opinionated, 


\section{International Journal of Science and Research (IJSR) \\ ISSN (Online): 2319-7064 \\ Index Copernicus Value (2013): 6.14 | Impact Factor (2015): 6.391}

condescending, and unfriendly" (p. 23) werelikely to be faced with students who do not participate in class. Even lecturing toooften decreases professors' ratings and student participation [63].[64] Found that students high in classroom apprehension feel nervous if the teacher stops talking or challenges them, and [65] noted thatwhen teachers challenged their students verbally, students were likely to becomedefensive and perceive the instructor as looking down on them. When students recognize their instructors as verbally aggressive, they are less likely to participate.

Alternatively, a climate where students and the teacher respect each other, wherethe students respect one another, and where the teacher cares about the students, is conducive to class participation, as it is this type of classroom climate that works to rise student confidence and relaxation in participation. [66] Said that it is important for instructors to encourage students to be respectful yet serious, while at the same time seeing the value in their ideas and admiring students when appropriate. [67] Noted that students were more motivated to speak up in class if they perceived theirinstructors as inclusive and appreciative of them and as using verbal approachstrategies. They were also more likely to participate if they observed their instructorsas physically or socially attractive.[68] Also found a positive relationship between teacher verbal and nonverbal feedback and student participation. [69] Noted that student-centered rather than teacher-centered classrooms weremore likely to have students with higher levels of participation; the ratio of professor:student speaking time was $58 \%$ to $42 \%$ in studentcentered classes and $68 \%$ to $32 \%$ in teacher-centered classes.[70] Also found that students were more likely to participateif they considered the atmosphere to be supportive, and noted that the professorshould work to create this type of situation by providing positive feedback andhandling contentious topics with grace. Though it would seem to impact a"comfortable" environment, the authors found that students' concerns about appearing "politically correct" (e.g., nonracist, nonsexist) did not impact their level of partaking in the classroom. [71] surveyed both students and professors and found that higherparticipation classes were more supportive, cooperative, and studentcentered, hadstudents who were less concerned about what others thought and interested in theirclassmates' opinions, and had professors who were approachable and knew theirstudents' names. It also has been found that students are more likely to ask questionsif they notice higher levels of support and lowerlevels of threat from their professors.

As part of creating a supportive climate, there are several characteristics of teachers that may encourage students to participate. One is being a good listenerand Cohen found that instructors can do this bylistening to their students' comments and questions without judging them, even if instructors do not agree with or want to listen to those explanations. Other teacherscharacteristics that can help to increase participation include: "enthusiasm and skillsas a facilitator of discussion", supportiveness, and patience and respect.[72] Suggested motivating students to participate by letting forsuccess, emphasizing cooperation over competition, setting high expectations, andStudent Participation 195 asking questions in a way that supports interaction. Following this suggestion of asking questions that encourage engagement, [73] proposed that questionsof interpretation, rather than of fact or assessment, are the only ones enough to havea good class discussion because there are no right answers. [74] Suggested asking fewer questions of fact. [75] suggested that instructors work on questioning techniques, start the course withtask-oriented questions, and have individual progress meetings with students*all to encourage question-asking in the classroom setting. [76] Suggested asking questions to which instructors do not know the answersthemselves and asking students whether or not they agree with other students' explanations. [77] found that the specific type of participation (e.g. direct questions, comments, factual questions) that students are best at answering will influence whether they will participate or not, with all students favoring different typesof questions.

Related to the type of question asked is the "wait time", allotted to answer thosequestions. [78] recommended increasing wait time, and[79] suggested that teachers should increase wait time to $3 \_5 \mathrm{~s}$ insteadof $1 \mathrm{~s}$ as is typical, and that they should purposely wait for students to elaborate ontheir answers before making any comments. [80] opposed that when teachers speak rapidly and do not allow for enough wait time, students recognizethat their participation is unwanted.Though it may seem counterintuitive to the finding on listening noted above, teacher self-disclosure has been found to have an impact on student participation.Goldstein and [81] noted both students and teachers reported higherlevels of student participation when instructors self-disclosed. The writers noted thatthese findings reveal that the reciprocity effect is in existence, that self-disclosuremakes the atmosphere more personal, and that the power differential between thestudents and teacher decreased. In a follow-up study, [82] found no relationship between observed student participation and observedinstructor self-disclosure, but a few years later, [83] again emphasizedthe importance of instructor self-disclosure in student participation, noting that itlessens the status differential between teachers and students, and in 2009 [84] found self-disclosure to be related to an increase in theparticipatory communication motive. A reason for these conflicting findings on theimpact of instructor selfdisclosure on participation may be dun part to what typesof information the teacher discloses. When students identify their teachers ashaving similar backgrounds or attitudes as them, they are more likely to take part, and less likely to participate if their instructors' political viewsare different from their own.[85] promoted instructors using empathy and getting to know studentsas individuals, allowing students to think that their professors care about them, thus increasing their participation. Similarly, [86] found that the singlelargest predictor of a student's participation was "faculty-student interaction", both inand out of the classroom setting (p. 587). When professors affirmed students' 196 K. A. Roccaparticipation and ideas, students were more likely to participate. [87] and noted that this type of caring atmosphere will encourage participationamong students and between students and teachers.

Another way the instructor can impact participation is through his/her level of "eye contact availability" .In this study, the teacher stood at one of four spots around the table inthe classroom, ranging from high to low in eye contact 


\section{International Journal of Science and Research (IJSR) \\ ISSN (Online): 2319-7064 \\ Index Copernicus Value (2013): 6.14 | Impact Factor (2015): 6.391}

availability with two of thefour positions showing medium eye contact availability.

According to viewers, when the instructor had high eye contact availability, students in those areas weremore likely to participate than those in low eye contact availability areas.[89] found that there were several relationships among teachervariables and student-perceived participation, but overall, student and logisticalvariables predicted $37 \%$ of the variance in class participation. However, within that $37 \%$, student confidence was the largest predictor, and of that predictor, there weresix variables that predicted confidence, one of which is whether or not the professoris offensive. The others were related to the student and to the classroom logistics.Clearly, the instructor plays a role in encouraging or discouraging studentparticipation, depending in part on whether he/she creates a supportive climate forthe students, but it is reasonable to consider the complexity of variables that impactparticipation in addition to the instructor.

\section{Sex Differences}

A substantial amount of research on participation has looked at student and/or teacher sex as a means of predicting participation, and overall, the findings aremixed. [90]found male students to participatemore than females, and [91] noted that this may be because they havehad more practice in doing so throughout their education. [92] foundthat males were more likely to participate and saw their own participation andparticipation in general as more important than females did. The finding of maleshaving a higher participation level is not surprising given the results of a met analysison sex and self-esteem, where females were found to have lower self-esteemthan males. If females do not think highlyof themselves, it makes sense that they would be less likely to participate in class, given the findings noted earlier linking confidence to participation.[93]however, found that females increased their partaking when they were encouragedby an experimental program titled "women speak this week," which permitted onlyfemales to speak in class during a designated week during the semester (p. 472). Inresearch on communication motives, [94] found that females weremore likely to take part for functional reasons and males for sycophantic reasons.

There is also evidence of differences between males and females in relation tostudent age. [95] found that students were likely toparticipate in this order: nontraditional-aged males, nontraditional-aged females, traditional-aged females, traditional-aged males, showing that the sex-age combinationis more predictive than sex or age alone. [96] also found age tobe a larger forecaster than sex with nontraditional students take part more thantraditional students. Nontraditional-aged females accounted for 41 percent of theparticipation in a study,but the majority of students at thatuniversity were nontraditional females.[97] found very little evidence of sex differences in their studyacross three different universities, and [98] found no difference inthe quantity of interactions between male and female students.

Concerning sex differences in teachers, female instructors were found to createan environment in which students would participate more, but that was not as strong of $198 \mathrm{~K}$. A. Roccaa predictor as class size was for participation, and the differences between male andfemale teachers did not impact the amount of participation by male or femalestudents. That is, the students participated regardlessof teacher sex, but female teachers had a tendency to get both male and femalestudents engaged more than male teachers did. [99] reported somewhat different findings. With female teachers, male students were found to speak andinterrupt more often, and to speak for longer durations than female students; nodifferences were found in courses taught by males. Brooks concluded that thesefindings may be explained by considering that female professors may encourage participation more than male professors. [100] alsofound differences with interrupting patterns*male professors were more likely tointerrupt their students than female instructors were. [101]found that students, especially males, were more likely to ask questions of maleteachers than female teachers. [102] found that students were more likely tofeel comfortable with participating in female-instructor courses. [103] found that students were more likely to participate frequentlyin male-instructor courses, but a higher percentage of students were morelikely to participate in femaleinstructor courses. [104] found no difference based on teachersex in student participation levels. Overall, it seems that the creation of acomfortable classroom climate is more important than instructor sex, and thatfemales may be more likely to create that type of environment. Again, itshould be emphasized that there are mixed results for the impact of professor sexon student participation, just as there are conflicting findings based solely on student sex.

A reason that there are conflicting findings when it comes to sex differences couldbe the way in which sex has been measured_as biological sex. The findings reportedthus far are based solely on biological sex, whether students are male or female. Inlooking at student questioning, [105] found few differences whenassessing biological sex, but when looking at gender, the psychological construct, theyfound that students who were masculine-oriented, regardless of biological sex, weremore likely to ask questions in class. In another study looking only at femaleparticipation behavior, [106] assessed the thinking and feelingdimensions (of the Myers-Briggs Type Indicator) with regard to classroom climate,and found that those scoring higher on the feeling dimension were more satisfiedwith the feeling classrooms, those with a lot of support and interaction, and thosewho scored higher on the thinking dimension had no preference; the authorspurported that it is not necessarily one's biological sex that determines participation,but a personality factor related to sex. This can help in explaining the mixture offindings related to teacher and student sex, as nearly every study assesses biologicalsex, not gender.

\section{Benefits of Getting Students to Participate In Classroom Discussions}

1) Participation adds interest - it's hard to maintain students' focus and attention when all they hear is the professor talking. It helps to hear another voice as well as an answer or another point of view.

2) Participation engages students - A good question can pique their interest, make them wonder why, get them to

\section{Volume 5 Issue 6, June 2016}




\section{International Journal of Science and Research (IJSR) \\ ISSN (Online): 2319-7064}

Index Copernicus Value (2013): 6.14 | Impact Factor (2015): 6.391

think, and motivate them to make connections with the content. This benefit is magnified when teachers play a bit with the question, when they repeat it, write it on the board, and don't call on the first hand they see.

3) Participation provides the teacher feedback-when students answer or try to explain, teachers can see the extent of their understanding. They can correct (or help the students correct) what the students haven't got right or don't see quite clearly.

4) Participation provides the students feedback-when teachers ask questions or otherwise seek student input over a topic, they are letting students know something about the importance of certain ideas and information.

5) Participation can be used to promote preparation-If an instructor regularly calls on students and asks questions about assigned reading or what's in their notes from the previous class session, that can get students (at least some of them) coming to class prepared.

6) Participation can be used to control what's happening in class - if a student is dozing off, texting, quietly chatting, or otherwise not attending to what's happening, that student can be called on or the student next to the offender can be asked to respond.

7) Participation can be used to balance who's contributing in class and how much - in the vast majority of cases, it is the teacher who selects the participant. If teachers will wait patiently and not always select the same student, if they look expectantly to others and confirm verbally and nonverbally the value of hearing from different people, they can influence who speaks and how much. Participation even helps teachers control how much they talk.

8) Participation encourages dialogue among and between students - Students can be asked to comment on what another student has said. A question can be asked and students can be invited to discuss possible answers with each other before the public discussion.

9) Participation can be used to develop important speaking skills - in many professional contexts, people need to be able to speak up in a group. They may need to offer information, ask questions, or argue for a different solution. People don't learn to speak up in a group by reading about how to do it - it's one of those skills best developed with practice. And it's one of those skills that develops better with feedback. If participation is being used to teach students this public communication skill, they will need feedback.

10) Participation gives students the opportunity to practice using the language of the discipline-Most faculty have spoken astronomy, accounting, psychology, gerontology, political science, whatever the field for years, and they've forgotten how much of the language is new, different, and difficult for students. Participation gives students the chance to practice using a different vocabulary.

\section{What Students Should Do for Classroom Participation}

- Don't be shyIf you are a naturally shy person, building a participation plan will be even more important.
- Don't give up! Over time you may find it easier to speak in class. Finally, remember that your instructors and peers are there to support and help you.

\subsection{Class Participation Starts before You even Get to Class}

To participate in class, you need to have a good understanding of the material you have covered up to that point. Review your study notes from the previous class or classes and make a list of concepts, ideas and facts to ask.

\subsection{Go to Class!}

Ok, this may sound really basic but it's important.You can't participate if you're not there. Whether being there means physically attending class or participating in an online chat or discussion board, you need to be there when it happens.

\subsection{What Does This Actually Mean?}

Arriving a few minutes late can throw off your ability to participate for the entire class and will probablybe disruptive. Arrive early and take a few moments to prepare yourself before the class begins. This is a good time for you to look over your notes and questions and refresh your mind about what you coveredin the last class and what today's class will cover.

\subsection{Ask a Question}

There are several ways you can participate in a class discussion.One way is to ask a question relevant to the material covered in class or in the readings.Asking a well thought out question lets the teacher know that you are engaged with the material. And often your classmates will be happy you asked a question they were thinking of too.

\subsection{Give and Take}

You may be asked to participate in a group activity in class.Be ready to work with others in a small group. Listen and interact with peers with respect for their views. Try not to sit silent or be the loudest. Be ready to give and take.Your teacher may ask for students to take part in a role play or activity. Do your best to participate fully. Becoming more involved in the activity will increase your interest and your learning.

\section{Conclusion}

The perfect class discussion" as one in which all students were participating, learning, and listening to others' ideas, comments, and questions, is important for the success of the class. Logistical issues, student confidence, and the instructor all have animportanteffect on student participation. A supportive classroom climate is critical to higher levels of participation. The more the students participate, the more they acquire, and the more they engage in higher levels of thinking, including interpretation, analysis, and synthesis. Class size has its effect on participation, students being more willing to participate in big size classes and less likely to be able to "hide" in 


\section{International Journal of Science and Research (IJSR) \\ ISSN (Online): 2319-7064 \\ Index Copernicus Value (2013): 6.14 | Impact Factor (2015): 6.391}

smaller classes than larger classes; large class size tends to ease communication. Students even reported confidence as the most motivating factor for their participation in several studies, by the fact that students who were supposed to talk about the topic with another student or to complete it as a homework assignment before discussing it with the entire class were more likely to participate.Students who are young, inexperienced, and immature are less likely to participate in class especially if they are surrounded by others who are more experienced.

Students' assertiveness and/or responsiveness also appear to determine whether or not they will participate in class. Those who are high in both traits are more likely to communicate for functional reasons, and those who are more assertive are more likely to communicate for excuse-making reasons. Students are less likely to participate if their instructors do not pay attention to them, make fun of them, put them down, or are very serious of them. Alternatively, a climate where students and the teacher respect each other, where the students respect one another, and where the teacher cares about the students, is conducive to class participation, as it is this type of classroom climate that works to rise student confidence and relaxation in participation. And finally, male students participate more than females, and noted that this may be because they have had more practice in doing so throughout their education. Concerning sex differences in teachers, female instructors were found to create an environment in which students would participate more.

\section{References}

[1] Dancer, D., \&Kamvounias, P. (2005). Student involvement in assessment: A project designed to assess class participation fairly and reliably. Assessment \& Evaluation in Higher Education, 30,445 454. (ES)

[2] Fritschner, L. M. (2000). Inside the undergraduate college classroom: Faculty and students differ on the meaning of student participation. The Journal of Higher Education, 71, 342 362. (LR)

[3] Burchfield, C. M., \& Sappington, J. (1999). Participation in classroom discussion. Teaching of Psychology, 26, 290 291. (ES)

[4] Fassinger, P. A. (1995b). Understanding classroom interaction. The Journal of Higher Education, 66, 82 96. (ES)

[5] Cohen, M. (1991). Making class participation a reality. PS: Political Science \& Politics, 24, 699703. (IT)

[6] Wade, R. (1994). Teacher education students' views on class discussion: Implications for fostering critical reflection. Teaching and Teacher Education, 10, 231 243. (ES)

[7] Junn, E. (1994). Pearls of wisdom: Enhancing student class participation with an innovative exercise. Journal of Instructional Psychology, 21, 385387. (ES)

[8] Lyons, P. R. (1989). Assessing classroom participation. College Teaching, 37, 36 38. (IT)

[9] Cohen, M. (1991). Making class participation a reality. PS: Political Science \& Politics, 24, 699703. (IT)
[10] Junn, E. (1994). Pearls of wisdom: Enhancing student class participation with an innovative exercise. Journal of Instructional Psychology, 21, 385387. (ES)

[11] Daggett, L. M. (1997). Teaching tools: Quantifying class participation. Nurse Educator, 22(2), 13 14. (IT)

[12] Crone, J. A. (1997). Using panel debates to increase student involvement in the introductory sociology class. Teaching Sociology, 25, 214 218. (IT)

[13] Kuh, G. D., \&Umbach, P. D. (2004). College and character: Insights from the National Survey of Student Engagement. New Directions for Institutional Research, 122, 37 54. (ES/R)

[14] Smith, D. G. (1977). College classroom interactions and critical thinking. Journal of Educational Psychology, 69, 180 190. (ES)

[15] Berdine, R. (1986). Why some students fail to participate in class. Marketing News, 20, 2324. (ASO)

[16] Armstrong, M., \&Boud, D. (1983). Assessing participation in discussion: An exploration of the issues. Studies in Higher Education, 8, 33 44. (ASO)

[17] Girgin, K. Z., \& Stevens, D. D. (2005). Bridging inclass participation with innovative instruction: Use and implications in a Turkish university classroom. Innovations in Education and Teaching International, 42, 93 106. (IT)

[18] Fassinger, P. A. (1995b). Understanding classroom interaction. The Journal of Higher Education, 66, 82 96. (ES)

[19] Fritschner, L. M. (2000). Inside the undergraduate college classroom: Faculty and students differ on the meaning of student participation. The Journal of Higher Education, 71, 342 362. (LR)

[20] Handelsman, M. M., Briggs, W. L., Sullivan, N., \&Towler, A. (2005). A measure of college student course engagement. The Journal of Educational Research, 98, 184 191. (ES)

[21] Wade, R. (1994). Teacher education students' views on class discussion: Implications for fostering critical reflection. Teaching and Teacher Education, 10, 231 243. (ES)

[22] Karp, D. A., \&Yoels, W. C. (1976). The college classroom: Some observations on the meanings of student participation. Sociology and Social Research, 60, 421 439. (ES)

[23] Cayanus, J. L., Martin, M. M., \&Goodboy, A. K. (2009). The relation between teacher selfdisclosure and student motives to communicate. Communication Research Reports, 26, 105 113. (ES)

[24] Howard, J. R., Short, L. B., \& Clark, S. M. (1996). Students' participation in the mixed-age college classroom. Teaching Sociology, 24, 8 24. (ES)

[25] Nunn, C. E. (1996). Discussion in the college classroom: Triangulating observational and survey results. The Journal of Higher Education, 67, 243 266. (ES)

[26] Pearson, J. C., \& West, R. (1991). An initial investigation of the effects of gender on student questions in the classroom: Developing a descriptive base. Communication Education, 40, 23 32. (ES)

[27] West, R. W., \& Pearson, J. C. (1994). Antecedent and consequent conditions of student questioning: An 


\section{International Journal of Science and Research (IJSR) \\ ISSN (Online): 2319-7064}

Index Copernicus Value (2013): 6.14 | Impact Factor (2015): 6.391

analysis of classroom discourse across the university. Communication Education, 43, 299 311. (ES)

[28] Berdine, R. (1986). Why some students fail to participate in class. Marketing News, 20, 2324. (ASO)

[29] Smith, D. H. (1992). Encouraging students' participation in large classes: A modest proposal. Teaching Sociology, 20, 337 339. (IT)

[30] Howard, J. R., Short, L. B., \& Clark, S. M. (1996). Students' participation in the mixed-age college classroom. Teaching Sociology, 24, 8 24. (ES)

[31] Karp, D. A., \&Yoels, W. C. (1976). The college classroom: Some observations on the meanings of student participation. Sociology and Social Research, 60, 421 439. (ES)

[32] Bowers, J. W. (1986). Classroom communication apprehension: A survey. Communication Education, 35, 372 378. (ES)

[33] Crombie, G., Pyke, S. W., Silverthorn, N., Jones, A., \&Piccinin, S. (2003). Students' perceptions of their classroom participation and instructor as a function of gender and context. Journal of Higher Education, 74, 51 76. (ES)

[34] McDaniel, T. R. (1984). A primer on motivation: Principles old and new. Phi Delta Kappan, 66, 4649. (ASO)

[35] Sprecher, S., \&Pocs, O. (1987). Teaching sexuality: Two techniques for personalizing the large class. Teaching Sociology, 15, 268 272. (IT)

[36] Gleason, M. (1986). Better communication in large classes. College Teaching, 34, 20 24. (ASO)

[37] Fritschner, L. M. (2000). Inside the undergraduate college classroom: Faculty and students differ on the meaning of student participation. The Journal of Higher Education, 71, 342 362. (LR)

[38] McCroskey, J. C., \&McVetta, R. W. (1978). Classroom seating arrangements: instructional communication theory versus student preferences. Communication Education, 27, 99 111. (ES)

[39] Neer, M. R., \&Kircher, W. F. (1989). Apprehensives' perception of classroom factors influencing their class participation. Communication Research Reports, 6, 70 77. (ES)

[40] Berdine, R. (1986). Why some students fail to participate in class. Marketing News, 20, 2324. (ASO)

[41] Fassinger, P. A. (1995a). Professors' and students' perceptions of why students participate in class. Teaching Sociology, 24, 25 33. (ES)

[42] Boniecki, K. A., \& Moore, S. (2003). Breaking the silence: Using a token economy to reinforce classroom participation. Teaching of Psychology, 30, 224 227. (ES)

[43] Yoakley, D. H. (1975). A study of student participation in classroom management to effect an increase in appropriate behavior. The Journal of Educational Research, 69, 31 35. (ES)

[44] Delprato, D. J. (1977). Increasing classroom participation with self-monitoring. The Journal of Educational Research, 70, 225 227. (ES)

[45] Dancer, D., \&Kamvounias, P. (2005). Student involvement in assessment: A project designed to assess class participation fairly and reliably.
Assessment \& Evaluation in Higher Education, 30, 445 454. (ES)

[46] Allred, C. R., \& Swenson, M. J. (2006). Using technology to increase student preparation for and participation in marketing courses: The random selector model. Marketing Education Review, 16, 15 21. (IT)

[47] Armstrong, M., \&Boud, D. (1983). Assessing participation in discussion: An exploration of the issues. Studies in Higher Education, 8, 33 44. (ASO)

[48] Howard, J. R., \&Henney, A. L. (1998). Student participation and instructor gender in the mixedage college classroom. The Journal of Higher Education, 69, 384 405. (ES)

[49] Hyde, C. A., \& Ruth, B. J. (2002). Multicultural content and class participation: Do students selfdisclose? Journal of Social Work Education, 38, 241 256. (ES)

[50] Cohen, M. (1991). Making class participation a reality. PS: Political Science \& Politics, 24, 699703. (IT)

[51] Crombie, G., Pyke, S. W., Silverthorn, N., Jones, A., \&Piccinin, S. (2003). Students' perceptions of their classroom participation and instructor as a function of gender and context. Journal of Higher Education, 74, 51 76. (ES)

[52] Crone, J. A. (1997). Using panel debates to increase student involvement in the introductory sociology class. Teaching Sociology, 25, 214 218. (IT)

[53] Wilcox, B. (1994). Involve everyone in class discussions. Learning, 22, 72 73. (ASO)

[54] Cohen, M. (1991). Making class participation a reality. PS: Political Science \& Politics, 24, 699703. (IT)

[55] Tatar, S. (2005). Why keep silent? The classroom participation experiences of non-nativeEnglishspeakingstudents. Language and Intercultural Communication, 5, 284 293. (ES)

[56] Booth-Butterfield, M. (1986). Stifle or stimulate? The effects of communication task structure on apprehensive and non-apprehensive students. Communication Education, 35, 337 348. (ES)

[57] Williams, R. (1971). Relationship of class participation to personality, ability, and achievement variables. The Journal of Social Psychology, 83, 193 198. (ES)

[58] Chan, B., \&McCroskey, J. C. (1987). The WTC scale as a predictor of classroom participation. Communication Research Reports, 4, 47 50. (ES)

[59] Karp, D. A., \&Yoels, W. C. (1976). The college classroom: Some observations on the meanings of student participation. Sociology and Social Research, 60, 421 439. (ES)

[60] Wade, R. (1994). Teacher education students' views on class discussion: Implications for fostering critical reflection. Teaching and Teacher Education, 10, 231 243. (ES)

[61] Kearney, P., Plax, T. G., Hays, E. R., \& Ivey, M. J. (1991). College teacher misbehaviors: What students don't like about what teachers say and do. Communication Quarterly, 39, 309 324. (ES)

\section{Volume 5 Issue 6, June 2016 www.ijsr.net}




\section{International Journal of Science and Research (IJSR) \\ ISSN (Online): 2319-7064}

Index Copernicus Value (2013): 6.14 | Impact Factor (2015): 6.391

[62] Berdine, R. (1986). Why some students fail to participate in class. Marketing News, 20, 2324. (ASO)

[63] Phoenix, C. Y. (1987). Get them involved! Styles of high- and low-rated teachers. College Teaching, 35, 13 15. (ES)

[64] Neer, M. R. (1987). The development of an instrument to measure classroom apprehension. Communication Education, 36, 154 166. (ES)

[65] Myers, S. A., \& Rocca, K. A. (2000). The relationship between perceived instructor communicator style, argumentativeness, and verbal aggressiveness. Communication Research Reports, 17, 1 12. (ES)

[66] Kelly, T. E. (1989). Leading class discussions of controversial issues. Social Education, 53, 368 370.(ASO)

[67] Mottet, T. P., Martin, M. M., \& Myers, S. A. (2004). Relationships among perceived instructor verbal approach and avoidance relational strategies and students' motives for communicating with their instructor. Communication Education, 53, 116122. (ES)

[68] Nadler, L. B., \& Nadler, M. K. (1990). Perceptions of sex differences in classroom communication. Women's Studies in Communication, 13, 46 65. (ES)

[69] Greeson, L. E. (1988). College classroom interaction as a function of teacher- and student-centered instruction. Teaching \& Teacher Education, 4, 305 315. (ES)

[70] Hyde, C. A., \& Ruth, B. J. (2002). Multicultural content and class participation: Do students selfdisclose? Journal of Social Work Education, 38, 241 256. (ES)

[71] Fassinger, P. A. (2000). How classes influence students' participation in college classrooms. Journal of Classroom Interaction, 35, 38 47. (ES)

[72] McDaniel, T. R. (1984). A primer on motivation: Principles old and new. Phi Delta Kappan, 66, 4649. (ASO)

[73] Gravett, D. J. (1985). Asking the right questions, a key to good class discussions. Teaching English in the Two-Year College, 12, 300 302. (ASO)

[74] Auster, C. J., \&MacRone, M. (1994). The classroom as a negotiated social setting: An empirical study of the effects of faculty members' behavior on students' participation. Teaching Sociology, 22, 289 300. (ES)

[75] Aitken, J. E., \&Neer, M. R. (1993). College student question-asking: The relationship of classroom communication apprehension and motivation. The Southern Communication Journal, 59, 73 81. (ES)

[76] Gravett, D. J. (1985). Asking the right questions, a key to good class discussions. Teaching English in the Two-Year College, 12, 300 302. (ASO)

[77] Berdine, R. (1986). Why some students fail to participate in class. Marketing News, 20, 2324. (ASO)

[78] Bean, J. C., \& Peterson, D. (1998). Grading classroom participation. New Directions for Teaching and Learning, 74, 33 40. (ASO)

[79] McDaniel, T. R. (1984). A primer on motivation: Principles old and new. Phi Delta Kappan, 66, 4649. (ASO)
[80] Fritschner, L. M. (2000). Inside the undergraduate college classroom: Faculty and students differ on the meaning of student participation. The Journal of Higher Education, 71, 342 362. (LR)

[81] Berdine, R. (1986). Why some students fail to participate in class. Marketing News, 20, 2324. (ASO)

[82] Wambach, C., \&Brothen, T. (1997). Teacher selfdisclosure and student classroom participation revisited. Teaching of Psychology, 24, 262 263. (ES)

[83] Fritschner, L. M. (2000). Inside the undergraduate college classroom: Faculty and students differ on the meaning of student participation. The Journal of Higher Education, 71, 342 362. (LR)

[84] Goldstein, G. S., \&Benassi, V. A. (1994). The relation between teacher self-disclosure and student classroom participation. Teaching of Psychology, 21, 212 217. (ES)

[85] Merwin, M. M. (2002). Let sleeping students lie? Using interpersonal activities to engage disengaged students. College Student Journal, 36, 87 93. (ASO)

[86] Weaver, R. R., \& Qi, J. (2005). Classroom organization and participation: College students' perceptions. The Journal of Higher Education, 76, 570 601. (ES)

[87] Gleason, M. (1986). Better communication in large classes. College Teaching, 34, 20 24. (ASO)

[88] Weaver, R. R., \& Qi, J. (2005). Classroom organization and participation: College students' perceptions. The Journal of Higher Education, 76, 570 601. (ES)

[89] Fassinger, P. A. (1995b). Understanding classroom interaction. The Journal of Higher Education, 66, 82 96. (ES)

[90] Crawford, M., \& MacLeod, M. (1990). Gender in the college classroom: An assessment of the 'chilly climate' for women. Sex Roles, 23, 101 122. (ES)

[91] Tannen, D. (1992). How men and women use language differently in their lives and in the classroom. The Education Digest, 57, 3 6. (ASO)

[92] Wade, R. (1994). Teacher education students' views on class discussion: Implications for fostering critical reflection. Teaching and Teacher Education, 10, 231 243. (ES)

[93] Wright, R. A., \& Kane, C. C. (1991). 'Women speak this week': Promoting gender equality and awareness in class discussions. Teaching Sociology, 19, 472 476. (IT)

[94] Myers, S. A., Martin, M. M., \&Mottet, T. P. (2002). Students' motives for communicating with their instructors: Considering instructor sociocommunicative style, student socio-communicative orientation, and student gender. Communication Education, 51, 121 133. (ES)

[95] Howard, J. R., \&Henney, A. L. (1998). Student participation and instructor gender in the mixedage college classroom. The Journal of Higher Education, 69, 384 405. (ES)

[96] Howard, J. R., Short, L. B., \& Clark, S. M. (1996). Students' participation in the mixed-age college classroom. Teaching Sociology, 24, 8 24. (ES)

[97] Cornelius, R. R., Gray, J. M., \& Constantinople, A. P. (1990). Student faculty interaction in the college 


\section{International Journal of Science and Research (IJSR) \\ ISSN (Online): 2319-7064}

Index Copernicus Value (2013): 6.14 | Impact Factor (2015): 6.391

classroom. Journal of Research and Development in Education, 23, 189 197. (ES)

[98] Boersma, P. D., Gay, D., Jones, R. A., Morrison, L., \&Remick, H. (1981). Sex differences in college student teacher interactions: Fact or fantasy? Sex Roles, 7, 775 784. (ES)

[99] Brooks, V. R. (1982). Sex differences in student dominance behavior in female and male professors' classrooms. Sex Roles, 8, 683 690. (ES)

[100] Nadler, L. B., \& Nadler, M. K. (1990). Perceptions of sex differences in classroom communication. Women's Studies in Communication, 13, 46 65. (ES)

[101] Pearson, J. C., \& West, R. (1991). An initial investigation of the effects of gender on student questions in the classroom: Developing a descriptive base. Communication Education, 40, 23 32. (ES)

[102] Bowers, J. W. (1986). Classroom communication apprehension: A survey. Communication Education, 35, 372 378. (ES)

[103] Howard, J. R., \&Henney, A. L. (1998). Student participation and instructor gender in the mixedage college classroom. The Journal of Higher Education, 69, 384 405. (ES)

[104] Boersma, P. D., Gay, D., Jones, R. A., Morrison, L., \&Remick, H. (1981). Sex differences in college student teacher interactions: Fact or fantasy? Sex Roles, 7, 775 784. (ES)

[105] Pearson, J. C., \& West, R. (1991). An initial investigation of the effects of gender on student questions in the classroom: Developing a descriptive base. Communication Education, 40, 23 32. (ES)

[106] Persaud, A., \& Salter, D. W. (2003). Understanding women's classroom 'fit' and participation as interactions between psychological and environmental types. Journal of Classroom Interaction, 38, 1 10. (ES) 